\title{
Pengaruh Motivasi dan Kinerja Terhadap Produktivitas Kerja Karyawan Tata Usaha PT Perkebunan Nusantara VI Kayu Aro
}

\author{
Alvia Santoni \\ Sekolah Tinggi Ilmu Ekonomi (STIE) Sakti Alam Kerinci \\ Email $\underline{\text { Alvia72@gmail.com }}$
}

\begin{abstract}
This study aimed to determine the effect of either simultaneously or partially, as well as where the most dominant variable affecting employee performance PT.Perkebunan Nusantara VI (Persero) Kayu Aro. Referring to the results of calculations where t count $>t$ table or 3.476>2.110, meaning that there is a significant relationship between work motivation to productivity. Variable performance of turns obtained tcount 3.573 with 0.002 significance level $(\alpha=$ 0.05> 0.002). Referring to the above calculation, can be determined as follows: where $t$ count $>t$ table or 3.573> 2.110, meaning that there is a significant relationship between performance of the Work Productivity of employees of PT. Nusantara Plantation VI Kayu Aro.Large Influence Work Motivation to Work Productivity of employees of PT. Nusantara Plantation VI Kayu Aro is of 41.5\%, while the contribution of performance variables affect the labor productivity amounted to 42.9\%. Large Work Motivation and Performance influence on employee productivity PT. Nusantara Plantation VI Kayu Aro together amounted to $47.8 \%$ while the remaining $52.2 \%$ can be explained by other causes.
\end{abstract}

\section{Keywords: Motivation, Performance, Work Productivity}

\section{PENDAHULUAN}

Produksi merupakan pusat pelaksanaan kegiatan yang konkrit bagi pengadaan barang dan jasa pada suatu badan usaha dan perusahaan. Proses produksi tersebut merupakan bagian yang terpenting dalam perusahaan, karena apabila berhenti maka perusahaan akan mengalami kerugian. Dalam kegiatan produksi faktor tenaga kerja (karyawan) mempunyai pengaruh besar, karena tenaga kerjalah yang melaksanakan proses produksi tersebut. Karyawan suatu perusahaan akan dapat bekerja dengan baik dalam menghasilkan suatu barang apabila mereka mempunyai minat dan semangat terhadap pekerjaan tersebut. Dengan demikian diperlukan suatu motivator bagi karyawan yaitu berupa pemenuhan kebutuhan fisik dan non fisik. Untuk itulah dibutuhkan suatu dorongan bagi karyawan di dalam menyelenggarakan kegiatan di suatu perusahaan.

Dorongan itulah yang disebut motivasi. Motivasi sebagaimana diungkapkan Wursanto (1988:132) adalah alasan, dorongan yang ada di dalam diri manusia yang menyebabkan manusia melakukan sesuatu atau berbuat sesuatu. Motivasi karyawan dapat dipengaruhi faktor minat, gaji yang diterima, kebutuhan akan rasa aman, hubungan antar personal dan kesempatan untuk bekerja. Dengan adanya motivasi dapat merangsang karyawan untuk lebih menggerakan tenaga dan pikiran dalam merealisasikan tujuan perusahaan.

Masalah sumber daya manusia saat ini masih tetap menjadi pusat perhatian dan tumpuhan bagi suatu organisasi atau perusahaan untuk dapat bertahan di era globalisasi yang diiringi dengan tingkat persaingan yang semakin 
ketat. Menurut Zahari (2015:45), Sumber daya manusia merupakan salah satu faktor produksi yang sangat penting di dalam menjalankan roda kegiatan dalam suatu perusahaan atau instansi. Hal ini menunjukkan bahwa manajemen sumber daya manusia merupakan kunci pokok yang harus diperhatikan dengan segala kebutuhannya. Salah satu pelaksanaan manajemen sumber daya manusia yaitu adanya sistem penilaian terhadap kinerja yang disebut dengan penilaian kinerja.

Penilaian ini bertujuan untuk menilai secara menyeluruh terhadap pelaksanaan pekerjaan serta perilaku kerja karyawan yang berada dalam organisasi untuk memastikan bahwa semua pekerjaan yang telah dilaksanakan berjalan sesuai dengan rencana yang telah ditentukan sebelumnya dan apabila terjadi suatu kesalahan atau penyimpangan maka pekerjaan tersebut dapat segera diperbaiki dan ditindaklanjuti sesuai dengan peraturan. Apabila kebutuhan serta keinginan karyawan sudah terpenuhi, maka mereka akan melaksanakan dan pekerjaanya dengan baik serta juga akan lebih bersemangat dalam bekerja sehingga karyawan itu memiliki kesanggupan atas tugas yang dibebankan, kesanggupan untuk bekerja sama serta sanggup menaati peraturan berorganisasi. Pra-survey yang telah dilakukan, bahwa :

1. Fakta mengenai motivasi kerja yang masih perlu diitingkatkan untuk meningkatkan kinerja karyawan, di mana karyawan membutuhkan adanya motivasi pemenuhan kebutuhan hirarki berupa pemenuhan kebutuhan aktualisasi diri, penghargaan, interaksi sosial, rasa aman dan pemenuhan kebutuhan terendah yaitu pemenuhan kebutuhan fisiologi. Terlihat masih banyak karyawan yang belum mampu mengembangkan potensinya sebagai aktualisasi diri, belum memberikan penghargaan atas hasil kerja yang dicapai, interaksi sosial masih bersifat individual yang berkaitan dengan hubungan antar karyawan belum bersifat hubungan sosial dalam unit kerja, belum merasa aman dan masih rendahnya pemberian kompensasi.

2. Keberhasilan suatu perusahaan dinilai berdasarkan kinerja karyawan, yang diukur berdasarkan penilaian kuantitas, kualitas, efisiensi dan efektivitas kerja yang ditunjukkan melalui serangkaian pelaksanaan aktivitas karyawan. Fenomena yang tercermin dari pengamatan pada PT. Perkebunan Nusantara VI (Persero) Kayu Aro. menunjukkan bahwa kinerja karyawan masih perlu diperbaiki. Fenomena kinerja karyawan tersebut terindikasi dari rendahnya kuantitas, kualitas, efisiensi dan efektivitas kerja dalam setiap pelaksanaan pekerjaan yang sesuai dengan penggunaan sumber daya manusia

3. Produktivitas kerja karyawan tata usaha PT. Perkebunan Nusantara VI Kayu Aro harus ditingkatkan lagi.

\section{Tabel 1}

Data Produksi PT.Perkebunan Nusantara VI Kayu Aro.

\begin{tabular}{ccr}
\hline Tahun & Daun Basah & Teh Kering \\
\hline 2009 & $27.268 .403 \mathrm{~kg}$ & $6.087 .940 \mathrm{~kg}$ \\
2010 & $26.853 .130 \mathrm{~kg}$ & $5.966 .234 \mathrm{~kg}$ \\
2011 & $26.798 .470 \mathrm{~kg}$ & $5.902 .567 \mathrm{~kg}$
\end{tabular}




\begin{tabular}{ccc}
\hline 2012 & $28.595 .735 \mathrm{~kg}$ & $6.960 .250 \mathrm{~kg}$ \\
2013 & $24.641 .249 \mathrm{~kg}$ & $4.967 .514 \mathrm{~kg}$ \\
2014 & $23.447 .905 \mathrm{~kg}$ & $4.817 .228 \mathrm{~kg}$ \\
RKAP'2015 & $22.975 .390 \mathrm{~kg}$ & $4.316 .255 \mathrm{~kg}$ \\
\hline
\end{tabular}

Sumber : PTP. Nusantara VI Unit Usaha Kayu Aro

Dilihat dari ketercapaian target produktivitasnya menujukkan ketidakstabilan, di mana produktivitas kerja karyawan dari tahun ke tahun terindikasi adanya penurunan, dan mengalami peningkatan yang kurang optimal, padahal produktivitas kerja ini sangat diperlukan bagi PT. (Persero) sebagai perusahaan yang bergerak dalam bidang usaha Produksi Teh hitam. Tujuan penelitian ini adalah untuk mengetahui pengaruh motivasi dan kinerja terhadap peningkatan produktivitas karyawan pada PT Perkebunan Nusantara VI Kayu Aro.

\section{METODE}

Metode pendekatan penelitian yang digunakan dalam penelitian ini adalah metode deskriptif kuantitatif. Metode deskriptif kuantitatif merupakan alat untuk menganalisis dengan melakukan perhitungan tingkat pengaruh Motivasi Kinerja terhadap Produktivitas Kerja Karyawan Tata Usaha PT. Perkebunan VI Kayu Aro.

\section{Populasi dan Sampel}

Populasi adalah semua unit analisis yang akan diteliti, baik lembaga maupun perorangan dalam wujud manusia, sebagai mana dikemukakan oleh Sugiono (2003:90), menyatakan bahwa populasi adalah wilayah generalisasi yang terdiri atas objek/subjek yang mempunyai kualitas dan karakteristik tertentu yang ditetapkan oleh peneliti untuk dipelajari dan kemudian ditarik kesimpulannya. Populasi dalam penelitian ini adalah seluruh karyawan yang mengelola bidang
Administrasi yang ada dalam Struktur organisasi PT Perkebunan Nusantara VI (Persero) Kayu Aro berjumlah 19 orang. Menurut Sugiyono (2003:91) sampel adalah sebagian dari jumlah dan karakteristik yang dimilikioleh populasi tersebut. Menurut Arikunto (1996:107) menyatakan bahwa apabila subyeknya kurang dari 100 orang, lebih baik diambil semuanya, maka penelitian ini disebut sebagi penelitian populasi.

\section{Responden}

Responden adalah: Obyek yang akan dimintai data atau menjawab pertanyaan dalam kuisioner yang diberikan, juga merupakan sampel yang ditetapkan jumlahnya, karena penelitian ini hanya menggunakan kuisioner maka responden adalah semua dari jumlah sampel yang telah ditetapkan.

\section{Teknik Pengumpulan Data}

Adapun teknik Pengumpulan Data yang digunakan dalam penelitian ini adalah sebagai berikut:

\section{Studi Kepustakaan (Library}

Research), yaitu mencari sumber informasi melalui buku-buku, dan yang berkaitan dengan dengan teori yang relevan bagi pembahasan masalah dan memperhatikan memperhatikan penelitian-penelitian yang pernah dilakukan oleh orang lain serta mencari berbagai artikel yang dapat membantu penulisdalam pembaha- san masalah.

2. Studi Lapangan (Field Research), yaitu pengumpulan data dengan cara penelitian langsung dengan menggunakan

Angket / 
quisioner, yaitu teknik pengumpulan data dengan cara mengajukan instrumen pertanyaan tertulis kepada responden yang dijawab secara tertulis pula oleh responden.

\section{Definisi Operasional Variabel} adalah: variabel dalam penelitian ini

1) Variabel Bebas (Independent Variable)

a. Motivasi (X1) merupakan proses mencoba mempengaruhi seseorang agar melaku kan sesuatu yang diinginkan (Zainun, 1989:62), sedangkan menurut Reksohadiprojo dan Handoko (1989:256) mendefinisikan motivasi merupakan keadaan dalam pribadi seseorang yang mendorong keinginan individu muntuk melakukan kegiatan-kegiatan tertentu guna mencapai suatu tujuan.

b. Kinerja pada dasarnya adalah apa yang dilakukan atau tidak dilakukan, pegawai sehingga mereka mempengaruhi seberapa banyak mereka memberi kontribusi kepada instansi atau organisasi termasuk kualitas pelayanan yang disajikan.

2) Variabel Dependent (Y)

Menurut Siagian, (1999:154), produktivitas kerja adalah kemampuan kemampuan memperoleh manfaat sebesarbesarnya dari sarana dan prasarana yang tersedia dengan menghasilkan output yang optimal, kalau mungkin yang maksimal. Indikator Produktivitas kerja adalah : (1) Produktivitas dikaitkan dengan waktu; (2) Produktivitas dihubungkan dengan Sumber Daya Insani; dan (3) Produktivitas dikaitkan dengan Sarana dan prasarana

\section{Interpretasi Data}

Sugiono

(1998:73)

menyatakan bahwa skala likert digunakan untuk mengukur sikap, pendapat dan persepsi seseorang atau sekelompok tentang kejadian atau gejala sosial. Berikut ini disajikan klasifikasi dan pemberian skor berdasarkan jawaban angket/kuesioner yang disebarkan :

Tabel 2

Daftar Jawaban dan Skor kuesioner

\begin{tabular}{clcc}
\hline No & \multicolumn{1}{c}{ URAIAN } & JAWABAN & SKOR \\
\hline 1 & Sangat Setuju ( SS ) & A & 5 \\
2 & Setuju ( S ) & B & 4 \\
3 & Ragu- Ragu ( RR ) & C & 3 \\
4 & Tidak Setuju ( TS ) & D & 2 \\
5 & Sangat Tidak Setuju ( STS ) & E & 1 \\
\hline
\end{tabular}

Sumber : Sugiono (1998:75)

Analisis Regresi Linier Berganda.

Analisis regresi linear berganda adalah suatu alat analisis peramalan nilai pengaruh dua variabel bebas atau lebih terhadap variabel terikat untuk membuktikan ada atau tidaknya pengaruh fungsi atau pengaruh kausal antara dua variabel bebas atau lebih dengan satu variabel terikat. Sugiono (2005:123). Dalam penelitian ini teknik analisa data yang digunakan adalah Regresi Linear berganda. Model persamaan 
untuk analisa regresi berganda adalah:

$\mathrm{Y}=\alpha+\beta_{1} \mathrm{X}_{1}+\beta_{2} \mathrm{X}_{2}+\mathrm{e}$

Dimana $\mathrm{Y}$ : Produktivitas

Karyawan; $\alpha$ : Konstanta; X1 :

Motivasi; X2 : Kinerja; $\beta_{1}$ :

Koefisien Regresi $\mathrm{X}_{1}$

$\beta_{2}$ : Koefisien Regresi $X_{2}$; e : Error

\section{Uji Hipotesis}

Untuk menguji hipotesis yang diajukan, maka dilakukan pengujian dengan Uji t dengan alpha $5 \%$ dengan menggunakan rumus :

$$
\begin{aligned}
t_{h} & =r_{y} \sqrt{\frac{n-2}{1-r_{x y}{ }^{2}}} \\
t_{h} & =\text { Nilai Uji t hitung } \\
\mathrm{r}_{\mathrm{y}} & =\text { Koofisien korelasi }
\end{aligned}
$$

Dengan ketentuan :

a. Apabila $t_{\text {hitung }}>t_{\text {tabel }}$ maka Ho ditolak dan Ha diterima, artinya ada pengaruh yang signifikan antara motivasi dan kinerja terhadap produktivitasi kerja karyawan.

b. Apabila $t_{\text {hitung }}<t_{\text {tabel }}$ maka Ho diterima dan Ha ditolak artinya tidak ada pengaruh yang signifikan antara motivasi dan kinerja terhadap produktivitaskerja karyawan.

\section{KoefisienDeterminasi}

Koefisien Determinasi digunakan untuk mengukur seberapa besar kontribusi variabel bebas (X) terhadap variabel terikat (Y). Teknik ini digunakan untuk mengetahui berapa persen besarnya pengaruh variabel bebas terhadap variabel terikat. Perhitungan dilakukan

dengan mengkuadratkan nilai koefesien korelasi dan dikalikan dengan $100 \%$, dengan rumusnya adalah :

$\mathrm{KD}=(\mathrm{rxy})^{2} \times 100 \%$

Keterangan: KD : Koefisien Determinasi; $r_{x y}=$ Koefisien person product moment antara $\mathrm{X}$ dan $\mathrm{Y}$

\section{Uji F}

Uji $F$ digunakan untuk mengetahui pengaruh variabel Motivasi dan Kinerja secara bersama-sama terhadap Produktivitas Kerja Karyawan Tata Usaha PT. (Persero) Perkebunan VI Kayu Aro.

- Jika $F_{\text {hitung }}>\mathrm{F}_{\text {tabel, }}$ maka Ho ditolak Ha diterima, artinya semua variabel independen secara bersama-sama memberikan pengaruh terhadap variabel dependen.

- Jika $F_{\text {hitung }}<\mathrm{F}_{\text {tabel, }}$ maka Ho diterima Ha ditolak, artinya tidak semua variabel independen secara bersama-sama memberikan pengaruh terhadap variabel dependen. Rumus yang digunakan untuk melakukan uji $\mathrm{F}$ tersebut adalah:

$$
\mathbf{F}=\frac{\mathbf{J K}(\operatorname{Reg}) / \mathbf{k}}{\mathbf{J K}(\mathrm{S}) /(\mathrm{n}-\mathrm{k}-1)}
$$

Keterangan : $F=$ Nilai $F$ Hitung; JK $($ Reg $)=$ Jumlah Kuadrat regresi; JK $(\mathrm{S})=$ Jumlah kuadrat sisa; $\mathrm{N}=$ Banyaknya sampel

\section{HASIL}

\begin{tabular}{|c|c|c|c|c|c|c|c|}
\hline \multirow{2}{*}{ Model } & \multicolumn{2}{|c|}{ Unstandardized Coefficients } & $\begin{array}{l}\text { Standardized } \\
\text { Coefficients }\end{array}$ & \multirow{2}{*}{$\mathrm{T}$} & \multirow{2}{*}{ Sig. } & \multicolumn{2}{|c|}{$95 \%$ Confidence Interval for B } \\
\hline & B & Std. Error & Beta & & & Lower Bound & Upper Bound \\
\hline 1 (Constant) & 15.618 & 7.594 & & 2.057 & .056 & -.481 & 31.717 \\
\hline Motivasi Kerja & .248 & .203 & .345 & 1.223 & .239 & -.182 & .678 \\
\hline
\end{tabular}

Tabel 3

Pengaruh Motivasi dan Kinerja Terhadap Produktivitas Kerja Karyawan Tata Usaha PT. Perkebunan Nusantara VI Kayu Aro 
Berdasarkan Tabel 3 terlihat bahwa nilai konstanta sebesar 15,618 dan koefisien Regresi b1 sebesar 0,248 sedangkan koefisien Regresi b2 sebesar 0,177 nilai konstanta dan koefisien regresi (a, b1 dan b2) ini dimasukkan dalam persamaan regresi linear berganda sebagai berikut :

$\mathrm{Y}=15,618+0,248 \mathrm{X} 1+0,177 \mathrm{X} 2$

Dengan penjelasan dari persamaan diatas adalah sebagai berikut :

1. Nilai $\mathrm{a}=15,618$ adalah nilai konstanta, artinya jika dianggap tidak ada Motivasi Kerja (motivasi kerja $=0$ ) dan Kinerja (kinerja $=0$ ) maka Produktivitas Kerja Karyawan PT. Perkebunan Nusantara VI (Persero) Kayu Aro akan meningkat sebesar 15,618.

2. Nilai $b 1=+0,248$ artinya tanda positif mengartikan bahwa terjadi peningkatan dari motivasi kerja, jika motivasi kerja dinaikkan $100 \%$ maka Produktivitas Kerja karyawan PT. Perkebunan Nusantara VI (Persero) Kayu Aro akan meningkat sebesar $24,8 \%$.

3. Nilai b2 $=+0,177$ artinya tanda positif mengartikan bahwa terjadi peningkatan dari kinerja, jika kinerja dinaikkan 100\% maka Produktivitas Kerja karyawan PT. Perkebunan Nusantara VI (Persero) Kayu Aro akan meningkat sebesar $17,7 \%$.

Seberapa besar Motivasi kerja dan Kinerja terhadap Produktivitas Kerja Karyawan PT. Perkebunan Nusantara VI Kayu Aro dapat dijelaskan pada tabel dibawah ini :

Tabel 4

Model Summary ${ }^{b}$

\begin{tabular}{|l|r|r|r|r|r|}
\hline Model & $\mathrm{R}$ & R Square & Adjusted R Square & \multicolumn{1}{|c|}{$\begin{array}{c}\text { Std. Error of the } \\
\text { Estimate }\end{array}$} & Durbin-Watson \\
\hline 1 & $.691^{\mathrm{a}}$ & .478 & .412 & 2.774 & 2.191 \\
\hline
\end{tabular}

Berdasarkan Tabel 4

dijelaskan bahwa $\mathrm{R}$ Square (determinasi) 0,478 atau sebesar 47,8\% kontribusi variabel Motivasi Kerja dan Kinerja Pegawai berpengaruh terhadap produktivitas kerja karyawan PT. Perkebunan Nusantara VI Kayu Aro, sedangkan sisanya sebesar $52,2 \%$ dapat dijelaskan oleh sebab-sebab lain.

\section{Uji F}

Uji statistik $F$ pada dasarnya menunjukkan apakah semua variabel independent yang dimasukkan dalam model mempunyai pengaruh secara bersama-sama (simultan) terhadap variabel dependent nya. Hasil perhitungan uji $\mathrm{F}$ ini dapat dilihat pada tabel berikut ini :

Tabel 5

ANOVA $^{b}$

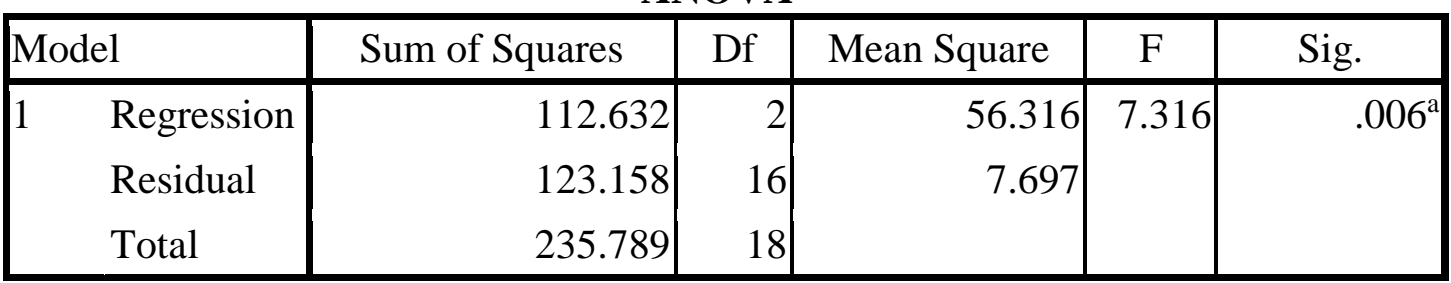


Berdasarkan Tabel 5, dapat diketahui nilai $F_{\text {hitung }}$ sebesar 7,316 sehingga dapat diputuskan sebagai berikut : dimana $F_{\text {hitung }}>F_{\text {tabel }}$ atau 7,316> 3,592 dengan tingkat signifikansi $0,006(\alpha=0,05>0,006)$. Berdasarkan hasil tersebut disimpulkan bahwa Ho ditolak $\mathrm{Ha}$ diterima yang berarti bahwa secara bersama-sama terdapat pengaruh yang signifikan antara Motivasi Kerja dan Kinerja terhadap Prodeuktivitas Kerja Karyawan PT. Perkebunan Nusntara VI Kayu Aro.

\section{SIMPULAN}

Hasil penelitian secara kuantitatif dalam penelitian ini dapat disimpulkan sebagai berikut :

1. Motivasi berpengaruh terhadap Produktivitas Kerja Karyawan Tata Usaha PT. Perkebunan Nusantara VI kayu Aro.Merujuk pada hasil perhitungan dimana $t_{\text {hitung }}>t_{\text {tabel }}$ atau 3,476 $>2,110$. Maka Ho ditolak Ha diterima, artinya terdapat pengaruh yang signifikan antara Motivasi Kerja terhadap Produktivitas. Selanjutnya untuk variabel kinerja ternyata didapat $t_{\text {hitung }}$ 3,573 dengan tingkat signifikansi $0,002(\alpha=0,05>0,002)$. Merujuk pada perhitungan diatas maka dapat diputuskan sebagai berikut : dimana $t_{\text {hitung }}>t_{\text {tabel }}$ atau 3,573 > 2,110. Maka Ho ditolak Ha diterima, artinya terdapat pengaruh yang signifikan antara Kinerja terhadap Produktivitas Kerja karyawan PT. Perkebunan Nusantara VI Kayu Aro.

2. Besar Pengaruh Motivasi Kerja terhadap Produktivitas Kerja karyawan Tata UsahaPT. Perkebunan Nusantara VI Kayu Aro adalah sebesar 41,5\%, sedangkan kontribusi variabel kinerja berpengaruh terhadap produktivitas kerjaadalah sebesar 42,9\%. Besar pengaruh Motivasi Kerja dan Kinerja terhadap produktivitas kerja karyawan Tata UsahaPT. Perkebunan Nusantara VI Kayu Aro secara bersama-sama adalah sebesar $47,8 \%$ sedangkan sisanya sebesar $52,2 \%$ dapat dijelaskan oleh sebab-sebab lain.

3. Variabel yang paling dominan mempengaruhi produktivitas kerja karyawanTata Usaha adalah Variabel Kinerja yaitu sebesar $42,9 \%$.

\section{DAFTAR PUSTAKA}

Dharma, Ali. 2003. Manajemen Sumber Daya Manusia. Badan Penerbit Fakultas Ekonomi, Yogyakarta.

Ghazali, Imam. 2004. Survei Diagnosis Organisasional Konsep dan Aplikasi, BPFE Undip, Semarang.

Hasibuan, Malayu SP. 2011. Manajemen Sumber Daya Manusia, Dasar dan Kunci Keberhasilan. Gunung Agung, Jakarta.

Mathis, Robert L, Jackson, John H. 2002. Manajemen Sumber Daya Manusia. Salemba Empat, Jakarta.

Purwadarminta, 2000, Manajemen Personalia,BPFE, Yogyakarta,

Srimulyo, 1999. Manajemen Sumber Daya Manusia. Buku 2 Jilid Pertama. Salemba Empat, Jakarta.

Sarwoto, Anwar. 2003. Dasar-dasar Perilaku Organisasi (Cetakan Pertama). UII Press, Yogyakarta.

Sugiyono, 2005, Statistika untuk Penelitian. Alfabeta. Bandung. 
Sopiah, 2008, Perilaku Organisasi, Andi Ofset, Yogyakarta.

Timpe, 2000, Manajemen Sumber

Daya Manusia. Mandar Baru, Bandung.

Tohardi, 2002, Manajemen Sumber Daya Manusia. Persada, Yogyakarta,

Tu'u. Consuelo G.et.al. 2004. Kedisiplinan. Penerjemah oleh Alimuddin Tuwu. Universitas Indonesia. Jakarta Unaragan. 2003. Manajemen Sumber Daya Manusia (Cetakan II). Penerbit STIE YKPN, Yogjakarta.

Wibowo. 2007. Manajemen Kinerja. PT Raja Grafindo Persada, Jakarta.

Zahari, M. 2015. Pengaruh Motivasi Terhadap Disiplin Kerja Pegawai pada Dinas Perindustrian dan Perdagangan Provinsi Jambi. Jurnal EKSIS, Vol.6, No.1, Mei 2015. 